\title{
Evaluating Challenges and Opportunities in the Development and Management of Physical Activity in Albania to Increase the Involvement of the Population in It
}

\author{
Rovena Elmazi \\ Junida Pogoni
}

Sports University of Tirana; Faculty of Physical activity and Recreation

\begin{abstract}
The study aims to assess the challenges, opportunities for development and management of physical activity in Albania compared to other countries in the region. The data collection tool included interviews, and the questionnaire used in all gyms in Albania. The result speaks of a huge gap with regard to the development of sports and the inclusion of populations in physical activities. According to the findings of the study, the number of population frequented by gyms in Albania. It is also worrying the very low number of female participants in the gym compared to the total number of women in the national level and the large difference in the number of males participating in physical activity and mainly in gymnasiums with the number of women that correctly reflected that in Albania it needs the revival and strengthening of gender mechanisms at national and local level. The result also revealed a lack of trained human resources, lack of policies and sound development strategies to increase population participation in physical activities. To this end, the National Sports and Regional Institutions, the Albanian Sports Federation and other relevant sports authorities should take all necessary measures to develop and expand the inclusion of populations into physical activities as a necessary means to increase the quality of life.
\end{abstract}

Keywords: challenges and opportunities, development, participation policies

\section{Introduction}

With increasing age, there is an increased risk of developing non-communicable chronic health conditions. ${ }^{2}$ In a recently published review, Blair et al emphasised the direct link between physical inactivity, low cardiovascular fitness and the presence of chronic health conditions. ${ }^{3}$

Five leading risk factors for death are high blood pressure, smoking, high blood glucose, physical inactivity and obesity. ${ }^{4} \mathrm{~A}$ glance at these risk factors reveals that high blood pressure and glucose levels as well as obesity are connected with physical inactivity. ${ }^{3}$ Alongside the increasing incidence of these risk factors with ageing, there is a decline in many physiological systems; a loss of muscle mass, a decline in balance ability, a reduction in muscle strength and endurance ${ }^{5}$ and a decline in cognitive performance, ${ }^{6}$ all of which impact on functional independence. Paterson et a/ ${ }^{1}$ suggested that increasing physical activity levels is the most important intervention to improve health in populations. For older adults, extending life is an important factor, but the maintenance of functional independence is also of high importance, both to maintain quality of life and to manage health resources. ${ }^{7}$ Therefore, it is important for anyone to spend some time doing sports recreational activities in closed encounters, in nature, in gyms to enhance the quality of life.

\section{Methodology}

A standardized questionnaire comprising open questions was used as an evaluating instrument and was submitted to owners, administrators and managers of fitness centers (when there was one in the surveyed areas) and Zumba, Pilates, Taekwondo and Kickboxing gyms. Data obtained from the questionnaire were further processed statistically to draw the results of the study.

309 fitness centers within the territory of Albania were the subject of the study. 


\section{The aim of the study}

The aim of this study is to highlight the participation of the Albanian population in organized sporting activities for all ages, to see and record the adequacy of sports centers in our country to meet the needs of the population and if we are working with professionalism from certified specialists such as one of the most important things to increase the participation. This study will serve to give a great help in participating in recreational activities for all age groups by increasing the quality of life.

No work has been done so far for the number of people involved and that are in the process in this area at Albanian institutions.

\section{Resuts}

1-Referring to the data on the number of gyms within the territory of the Republic of Albania, the results are as follow. What strikes from the data listed in the table is the low number of gyms in most cities and districts, and the sharp contrast with the situation in the capital of the country, where the number of gyms outdoes by many times that of the gyms in districts such as Vlora, Shkodra, Durresi, Lezha, and the insignificant number found in the districts of Dibra, Kukes Gjirokaster, Berat, etc.

The following tables reflect the distribution of the gyms according to the Circles in Albania

\begin{tabular}{|c|c|c|c|c|c|}
\hline \multicolumn{5}{|c|}{ Distibution according to the Circle of Albania } & \multirow[b]{2}{*}{$\begin{array}{l}\text { Cumulative } \\
\text { Percent }\end{array}$} \\
\hline & & Frequency & Percent & $\begin{array}{l}\text { Valid } \\
\text { Percent }\end{array}$ & \\
\hline \multirow[t]{13}{*}{ Valid } & BERAT & 5 & 1.7 & 1.7 & 1.7 \\
\hline & DIBER & 2 & 0.7 & 0.7 & 2.4 \\
\hline & DURRES & 15 & 5.1 & 5.1 & 7.5 \\
\hline & ELBASAN & 4 & 1.4 & 1.4 & 8.8 \\
\hline & FIER & 9 & 3.1 & 3.1 & 11.9 \\
\hline & GJIROKAS & 5 & 1.7 & 1.7 & 13.6 \\
\hline & KORCE & 6 & 2.0 & 2.0 & 15.6 \\
\hline & KUKES & 5 & 1.7 & 1.7 & 17.3 \\
\hline & LEZHE & 10 & 3.4 & 3.4 & 20.7 \\
\hline & SHKODER & 12 & 4.1 & 4.1 & 24.8 \\
\hline & TIRANE & 200 & 68.0 & 68.0 & 92.9 \\
\hline & VLORE & 21 & 7.1 & 7.1 & 100.0 \\
\hline & Total & 309 & 100.0 & 100.0 & \\
\hline
\end{tabular}

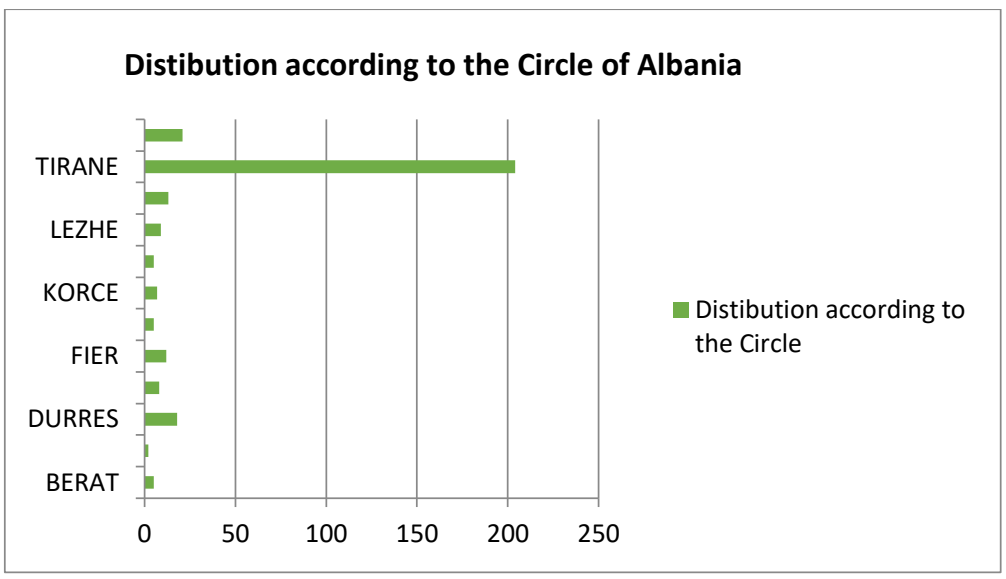




\begin{tabular}{|c|c|c|c|c|c|}
\hline \multicolumn{6}{|c|}{ Distibution according to the Citys of Albania } \\
\hline & & Frequency & Percent & Valid Percent & $\begin{array}{l}\text { Cumulative } \\
\text { Percent }\end{array}$ \\
\hline \multirow[t]{35}{*}{ Valid } & BERAT & 4 & 1.4 & 1.4 & 1.4 \\
\hline & BIBER & 1 & 0.3 & 0.3 & 1.7 \\
\hline & DURRES & 12 & 4.1 & 4.1 & 5.8 \\
\hline & ELBASAN & 6 & 1.0 & 1.0 & 6.8 \\
\hline & ERSEKE & 1 & 0.3 & 0.3 & 13.9 \\
\hline & FIER & 6 & 2.0 & 2.0 & 8.8 \\
\hline & FUSHE KRUJE & 3 & 1.0 & 1.0 & 17.3 \\
\hline & GJIROKAS & 3 & 1.0 & 1.0 & 9.9 \\
\hline & KAVAJE & 3 & 1.0 & 1.0 & 9.9 \\
\hline & GRAMSH & 1 & 0.3 & 0.3 & 10.2 \\
\hline & KORCE & 3 & 1.0 & 1.0 & 11.2 \\
\hline & KRUJE & 6 & 1.0 & 1.0 & 12.2 \\
\hline & KUCOV & 1 & 0.3 & 0.3 & 12.6 \\
\hline & KUKES & 2 & 0.7 & 0.7 & 13.3 \\
\hline & KURBIN & 1 & 0.3 & 0.3 & 13.6 \\
\hline & LAC,KURB & 1 & 0.3 & 0.3 & 13.9 \\
\hline & LEZHE & 7 & 2.4 & 2.4 & 16.3 \\
\hline & LIBRAZHD & 1 & 0.3 & 0.3 & 13.9 \\
\hline & LUSHNJE & 3 & 1.0 & 1.0 & 17.3 \\
\hline & MALLAKASTER & 1 & 0.3 & 0.3 & 13.9 \\
\hline & MALESI E MADHE & 1 & 0.3 & 0.3 & 13.9 \\
\hline & MAMURRAS & 1 & 0.3 & 0.3 & 17.7 \\
\hline & MAT & 1 & 0.3 & 0.3 & 18.0 \\
\hline & MIRDITE & 1 & 0.3 & 0.3 & 19.7 \\
\hline & PERMET & 1 & 0.3 & 0.3 & 18.4 \\
\hline & POGRADEC & 3 & 1.0 & 1.0 & 19.4 \\
\hline & RROGOZHINE & 1 & 0.3 & 0.3 & 25.5 \\
\hline & PUKE & 1 & 0.3 & 0.3 & 19.7 \\
\hline & SARANDE & 5 & 1.7 & 1.7 & 21.4 \\
\hline & SHKODER & 11 & 3.7 & 3.7 & 25.2 \\
\hline & TEPELENE & 1 & 0.3 & 0.3 & 25.5 \\
\hline & TIRANE & 200 & 68.0 & 68.0 & 93.5 \\
\hline & TROPOJE & 3 & 1.0 & 1.0 & 94.6 \\
\hline & VLORE & 16 & 5.4 & 5.4 & 100.0 \\
\hline & Total & 309 & 100.0 & 100.0 & 100.0 \\
\hline
\end{tabular}

In the tables and graphs that follow you find the number of population having a gym membership at district and country level, and the number according to gender divisions as compared to the number of population. From the data obtained it results that the number of people working out in gyms is relatively low as compared to the overall population at district and country level pointing to the fact that physical activity is not an important aspect in the life of people in general, what might be due to economical, social, cultural and psychological factors. Another important finding from the study is that the number of boys that frequent gyms is many times higher than that of women for all districts and at national level.

\begin{tabular}{|c|c|c|c|c|c|c|c|c|c|}
\hline \multirow[b]{2}{*}{ Qarku } & \multicolumn{9}{|l|}{ YEAR 2017} \\
\hline & $\begin{array}{l}\text { MALES IN } \\
\text { ALL } \\
\text { ALBANIA }\end{array}$ & $\begin{array}{l}\text { MALES } \\
\text { ATTENDED } \\
\text { GYMS }\end{array}$ & $\%$ & $\begin{array}{l}\text { FEMALE IN } \\
\text { ALL } \\
\text { ALBANIA }\end{array}$ & $\begin{array}{l}\text { FEMALE } \\
\text { ATTENDE } \\
\text { D GYMS }\end{array}$ & $\%$ & $\begin{array}{l}\text { POPULATION } \\
\text { NUMBER OF } \\
\text { ALBANIA }\end{array}$ & $\begin{array}{l}\text { POPULATI } \\
\text { ON }\end{array}$ & $\%$ \\
\hline
\end{tabular}




\begin{tabular}{|c|c|c|c|c|c|c|c|c|c|}
\hline & & & & & & & & $\begin{array}{l}\text { ATTENDE } \\
\text { D GYMS }\end{array}$ & \\
\hline Berat & 67,397 & 280.00 & $\begin{array}{l}0 . \\
4\end{array}$ & 64,545 & 46.00 & 0.1 & 131,942 & 326 & 0.2 \\
\hline Dibër & 65,742 & 110.00 & $\begin{array}{l}0 . \\
2\end{array}$ & 59,837 & 50.00 & 0.1 & 125,579 & 160 & 0.1 \\
\hline Durrës & 145,390 & 1012.00 & $\begin{array}{l}0 . \\
7\end{array}$ & 139,433 & 969.00 & 0.7 & 284,823 & 1,981 & 0.7 \\
\hline Elbasan & 144,258 & 180.00 & $\begin{array}{l}0 . \\
1\end{array}$ & 139,564 & 210.00 & 0.2 & 283,822 & 390 & 0.1 \\
\hline Fier & 155,524 & 620.00 & $\begin{array}{l}0 . \\
4\end{array}$ & 146,983 & 270.00 & 0.2 & 302,507 & 890 & 0.3 \\
\hline Gjirokastër & 33,191 & 222.00 & $\begin{array}{l}0 . \\
7\end{array}$ & 32,748 & 90.00 & 0.3 & 65,939 & 312 & 0.5 \\
\hline Korçë & 108,337 & 342.00 & $\begin{array}{l}0 . \\
3\end{array}$ & 105,984 & 278.00 & 0.3 & 214,321 & 620 & 0.3 \\
\hline Kukës & 40,925 & 340.00 & $\begin{array}{l}0 . \\
8\end{array}$ & 38,634 & 80.00 & 0.2 & 79,559 & 420 & 0.5 \\
\hline Lezhë & 65,642 & 317.00 & $\begin{array}{l}0 . \\
5\end{array}$ & 63,377 & 107.00 & 0.2 & 129,019 & 424 & 0.3 \\
\hline Shkodër & 103,370 & 690.00 & $\begin{array}{l}0 . \\
7 \\
\end{array}$ & 104,554 & 445.00 & 0.4 & 207,924 & 1,135 & 0.5 \\
\hline Tiranë & 427,915 & 14696.00 & $\begin{array}{l}3 . \\
4\end{array}$ & 434,446 & 10642.00 & 2.4 & 862,361 & 25,338 & 2.9 \\
\hline Vlorë & 95,850 & 1172.00 & $\begin{array}{l}1 . \\
2\end{array}$ & 92,945 & 635.00 & 0.7 & 188,795 & 1,807 & 1.0 \\
\hline $\begin{array}{l}\text { Gjithsej / } \\
\text { Total }\end{array}$ & $1,453,541$ & 19981.00 & $\begin{array}{l}1 . \\
4\end{array}$ & $1,423,050$ & 13822.00 & 1.0 & $2,876,591$ & 33,803 & 1.2 \\
\hline
\end{tabular}

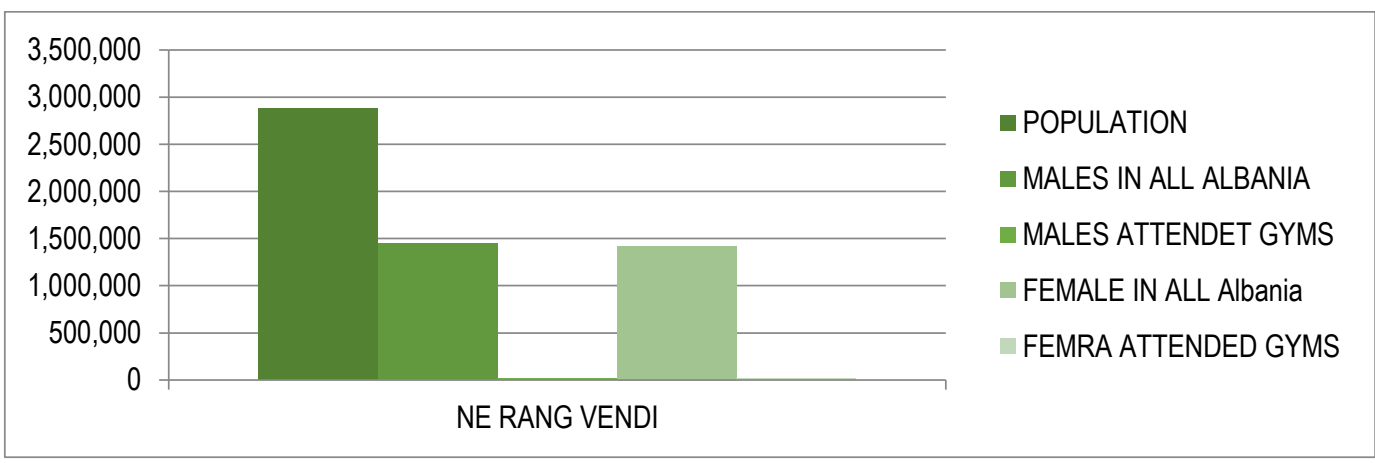


Besides results according to gender divisions, the study also obtained data on the number of gym memberships based on age divisions. In the table and graph displayed we have included results for every age, but l'd like to clarify that the data for the age groups of 2-6 years and 7-12 years have resulted from sports centers which include pools and which offer swimming classes for these age groups. Whereas gym memberships are held by adults more precisely; youngsters, middle aged and elderly people. The data collected speak for a considerable number of youngsters aged 18-30 years having a gym membership, a tendency observed even in the group of 31-40 years of age, while a plummeting of the numbers is recorded in the age group of 41-50 years and an insignificant number can be observed among the age group of 51-60 years.

\begin{tabular}{|l|l|l|l|l|l|l|l|l|l|}
\hline \multirow{2}{*}{ CIRCLE } & $\begin{array}{l}02-06 \\
\text { years }\end{array}$ & $\begin{array}{l}7-12 \\
\text { years }\end{array}$ & $\begin{array}{l}13-18 \\
\text { years }\end{array}$ & $\begin{array}{l}19-30 \\
\text { years }\end{array}$ & $\begin{array}{l}31-40 \\
\text { years }\end{array}$ & $\begin{array}{l}41-50 \\
\text { years }\end{array}$ & $\begin{array}{l}51-60 \\
\text { years }\end{array}$ & $61+$ & \multirow{2}{*}{ TOTAL } \\
\hline BERAT & 0.00 & 0.00 & 39.00 & 138.00 & 149.00 & 0.00 & 0.00 & 0.00 & 326.00 \\
\hline DIBER & 0.00 & 0.00 & 40.00 & 80.00 & 40.00 & 0.00 & 0.00 & 0.00 & 160.00 \\
\hline DURRES & 0.00 & 0.00 & 295.00 & 717.00 & 480.00 & 430.00 & 59.00 & 10.00 & 1991.00 \\
\hline ELBASAN & 0.00 & 0.00 & 10.00 & 100.00 & 190.00 & 90.00 & 0.00 & 0.00 & 390.00 \\
\hline FIER & 0.00 & 0.00 & 80.00 & 360.00 & 320.00 & 130.00 & 0.00 & 0.00 & 890.00 \\
\hline GJIROKAS & 0.00 & 0.00 & 25.00 & 101.00 & 145.00 & 41.00 & 0.00 & 0.00 & 312.00 \\
\hline KORCE & 10.00 & 13.00 & 92.00 & 255.00 & 165.00 & 77.00 & 8.00 & 0.00 & 620.00 \\
\hline KUKES & 0.00 & 0.00 & 100.00 & 110.00 & 210.00 & 0.00 & 0.00 & 0.00 & 420.00 \\
\hline LEZHE & 0.00 & 13.00 & 49.00 & 228.00 & 96.00 & 38.00 & 0.00 & 0.00 & 424.00 \\
\hline SHKODER & 0.00 & 0.00 & 199.00 & 410.00 & 305.00 & 201.00 & 10.00 & 10.00 & 1135.00 \\
\hline TIRANE & 260.00 & 636.00 & $\begin{array}{l}2938.0 \\
0\end{array}$ & 8193.00 & 8580.00 & 4063.00 & 593.00 & 85.00 & 25348.00 \\
\hline VLORE & 43.00 & 89.00 & 233.00 & 719.00 & 417.00 & 237.00 & 67.00 & 2.00 & 1807.00 \\
\hline TOTAL & 313.00 & 751.00 & $\begin{array}{l}4100.0 \\
0\end{array}$ & $\begin{array}{l}11411.0 \\
0\end{array}$ & $\begin{array}{l}11097.0 \\
0\end{array}$ & 5307.00 & 737.00 & 107.00 & 33823.00 \\
\hline
\end{tabular}

\begin{tabular}{|c|c|c|c|c|c|c|c|c|}
\hline & $\begin{array}{l}02-06 \\
\text { VJEC }\end{array}$ & 7-12 VJEC & $\begin{array}{l}13-18 \\
\text { VJEC }\end{array}$ & $\begin{array}{l}19-30 \\
\text { VJEC }\end{array}$ & $\begin{array}{l}31-40 \\
\text { VJEC }\end{array}$ & $\begin{array}{l}41-50 \\
\text { VJEC }\end{array}$ & $\begin{array}{l}51-60 \\
\text { VJEC }\end{array}$ & $61+$ \\
\hline CIRCLE & TOTAL & TOTAL & TOTAL & TOTAL & TOTAL & TOTAL & TOTAL & TOTAL \\
\hline BERAT & 0.00 & 0.00 & 11.96 & 42.33 & 45.71 & 0.00 & 0.00 & 0.00 \\
\hline DIBER & 0.00 & 0.00 & 25.00 & 50.00 & 25.00 & 0.00 & 0.00 & 0.00 \\
\hline DURRES & 0.00 & 0.00 & 14.82 & 36.01 & 24.11 & 21.60 & 2.96 & 0.50 \\
\hline ELBASAN & 0.00 & 0.00 & 2.56 & 25.64 & 48.72 & 23.08 & 0.00 & 0.00 \\
\hline FIER & 0.00 & 0.00 & 8.99 & 40.45 & 35.96 & 14.61 & 0.00 & 0.00 \\
\hline GJIROKAS & 0.00 & 0.00 & 8.01 & 32.37 & 46.47 & 13.14 & 0.00 & 0.00 \\
\hline KORCE & 1.61 & 2.10 & 14.84 & 41.13 & 26.61 & 12.42 & 1.29 & 0.00 \\
\hline KUKES & 0.00 & 0.00 & 23.81 & 26.19 & 50.00 & 0.00 & 0.00 & 0.00 \\
\hline LEZHE & 0.00 & 3.07 & 11.56 & 53.77 & 22.64 & 8.96 & 0.00 & 0.00 \\
\hline SHKODER & 0.00 & 0.00 & 17.53 & 36.12 & 26.87 & 17.71 & 0.88 & 0.88 \\
\hline TIRANE & 1.03 & 2.51 & 11.59 & 32.32 & 33.85 & 16.03 & 2.34 & 0.34 \\
\hline VLORE & 2.38 & 4.93 & 12.89 & 39.79 & 23.08 & 13.12 & 3.71 & 0.11 \\
\hline TOTAL & 0.93 & 2.22 & 12.12 & 33.74 & 32.81 & 15.69 & 2.18 & 0.32 \\
\hline
\end{tabular}




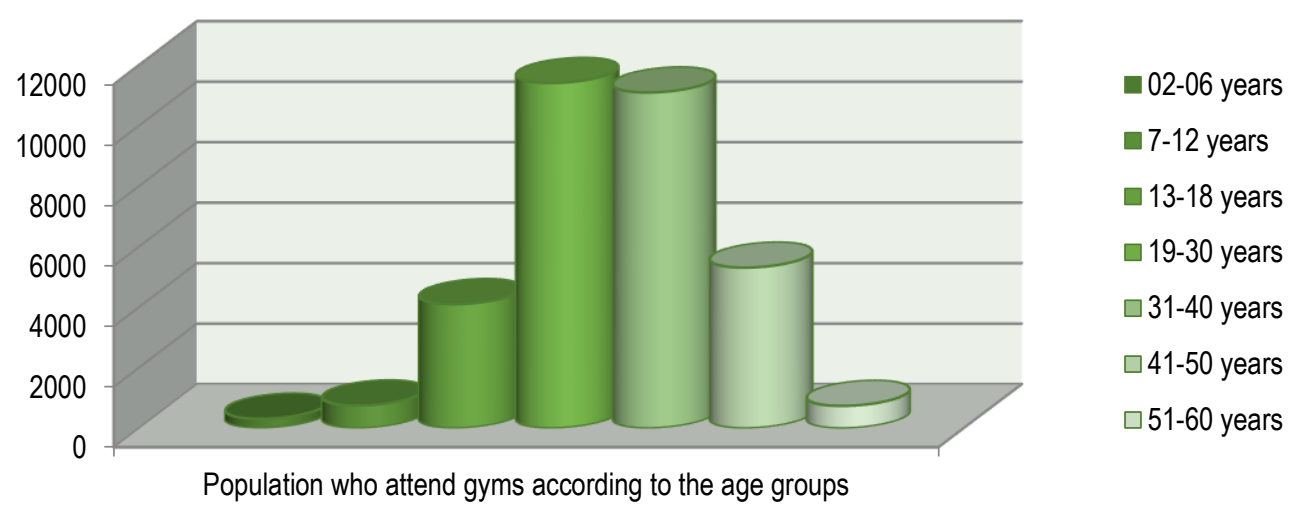

\section{Discution and Conclusion}

Data on the number of gyms located in the territory of the Republic of Albania are a clear indication of the low number of gyms in most of the cities and regions and the difference of the number of gyms in the capital city with the number of gyms in the regions, which is many times more than in regions including Vlora, Shkodra, Durresi, Lezha and an insignificant number in other regions including Dibra, Kukes, Gjirokastra, Berat etc. The number of the population enrolled in these gyms at regional and national level and the number by gender categories compared to the total number of the population show that the number of people enrolled in these gyms is very much low compared to the total number of the population in regions and at national level. This is a proof that in our country physical activity is not an important part of the life of the population, and this phenomenon may be happening because of different economic, social, cultural or psychological phenomena.

Another important result of this study is the number of males enrolled in the gyms which is higher compared to the number of females in all the regions and at national level. It must be noted that in the smaller regions including Berat, Dibra, Gjirokastra, Kukesi etc the participation of females is quite low, compared to males.

The study, in addition to the gender category, considers even the age groups enrolled in the fitness centers. The gyms are mostly attended by adults: young people, middle age and third age. There is a high number of the young people aged 1318 and the involvement of the population of the age group 19-30 and 31-40 years of age. There is a sharp decrease of the number of those aged 41-50 and even more so of those aged 51-60. Such low number of persons of this age group attending the gyms must be studies from a broader point of view, in all the possible social, economic, cultural, physiological, psychological components etc.

An important aspect pointed out in this study is the shortage of the professional trainers and their education as an important factor to have professional gyms as the key to having an increase number of people attending them. The statistics show that the gyms in our country do not provide services of the proper standards because there are only a limited number of trainers, two per each gym, and an average number of clients of 90 persons, which means that 1 trainer must prepare a training plan for 45 clients per day and it is impossible in this situation to perform quality service. Not only does the high number of clients per trainer infringes the standards, but also their education does not correspond to the work they carry out. The results show that most of the trainers are teachers of physical education, other are trainers who have completed another education, and only a few of them are trainers who have the relevant education for this occupation. Physical activity and recreation "fitness trainer.

\section{Further Implication}

Further study will be needed to find the reason why there are few fitness center in most of the cities in our country and why are they attended by a low number of the population. There is a big difference of these components with the capital city. Additional study should consider as well the third age group in several physiological, psychological, social etc aspects as they do not go to the fitness center, but maybe they are involved in other recreational activity. Another study must concern 
the considerable difference between the number of males and females attending the gyms, the reason behind, whether for economic reasons or social conservative reasons.

\section{References}

[1] 1.Paterson D, Jones G, Rice C. Ageing and physical activity: evidence to develop exercise recommendations for older adults. Appl Physiol Nutr Metab 2007;32(Suppl 2E):S69-108.CrossRefGoogle Scholar

[2] 2. World Health Organization. Global health risks: mortality and burden of disease attributable to selected major risks. Geneva: WHO, 2009.

[3] 3.Lau RS, Ohinmaa A, Johnson JA. Predicting the future burden of diabetes in Alberta from 2008 to 2035. Can J Diabetes2011;35:274-81.CrossRefWeb of ScienceGoogle Scholar

[4] 4.World Health Organization. Global recommendations on physical activity for health. Geneva: World Health Organisation, 2010.

[5] 5.Sakuma K, Yamaguchi A. Sarcopenia and age-related endocrine function. Int J Endocrinol 2012;2012(Article ID 127362):10.Google Scholar

[6] 6.Salthouse TA. Memory aging from 18 to 80. Alzheimer Dis Assoc Disord 2003;17:1627CrossRefPubMedWeb of ScienceGoogle Scholar

[7] 7.Lau RS, Ohinmaa A, Johnson JA. Predicting the future burden of diabetes in Alberta from 2008 to 2035. Can J Diabetes2011;35:274-81.CrossRef, Web of Science, Google Scholar 